\title{
Solvent Extraction Separation of Silver(I) and Zinc(II) from Nitrate Leach Solution of Spent Silver Oxide Batteries with D2EHPA
}

\author{
Sung-Yong Cho, Won-geun Lee and Pan-Pan Sun* \\ Department of Environment and Energy Engineering, Chonnam National University, Gwangju 61186, Republic of Korea
}

In this study, separation of silver(I) and zinc(II) from nitrate leach solution of spent silver oxide batteries were carried out by extraction and selective stripping. Di-(2-ethylhexyl) phosphoric acid (D2EHPA) was used to extract $\mathrm{Zn}(\mathrm{II})$ and $\mathrm{Ag}(\mathrm{I})$ in the equilibrium pH range of 0.99-1.34. The extraction of $\mathrm{Zn}(\mathrm{II})$ was more affected by the $\mathrm{pH}$ value than that of $\mathrm{Ag}(\mathrm{I})$. $\mathrm{Zn}(\mathrm{II})$ and $\mathrm{Ag}(\mathrm{I})$ loaded in D2EHPA was separated by selective stripping with a mixture of $0.01 \mathrm{~mol} / \mathrm{dm}^{3}$ nitric acid and $1 \mathrm{~mol} / \mathrm{dm}^{3}$ thiourea and $0.5 \mathrm{~mol} / \mathrm{dm}^{3}$ nitric acid for Ag(I) and Zn(II), sequentially. A process flowsheet for the separation and recovery of $\mathrm{Zn}(\mathrm{II})$ and $\mathrm{Ag}(\mathrm{I})$ from the nitrate leach solution of spent silver oxide batteries was proposed. [doi:10.2320/matertrans.M2018394]

(Received December 26, 2018; Accepted March 29, 2019; Published May 25, 2019)

Keywords: silver, zinc, D2EHPA, separation, silver oxide batteries

\section{Introduction}

Silver oxide batteries are widely used in electronic products such as electric watches, portable medical monitors, calculators, digital thermometers, and toys. ${ }^{1)}$ Spent silver oxide batteries resources is becoming an attractive proposition because of the depletion of natural resources and the increasing strictness of environmental policies. ${ }^{1-4)}$

In the hydrometallurgical treatment of silver oxide batteries, $\mathrm{Ag}$ and $\mathrm{Zn}$ are dissolved with nitric acid $\left(\mathrm{HNO}_{3}\right)$ solution and fermentation liquor.,5) The separation of $\mathrm{Ag}$ and $\mathrm{Zn}$ from various media have been investigated via precipitation, ${ }^{5)}$ ion exchange followed by selective elution ${ }^{7)}$ and solvent extraction ${ }^{8-10)}$ among other methods. Di-(2ethylhexyl) phosphoric acid (D2EHPA) has been used for the extraction/separation of $\mathrm{Zn}$ (II) from solutions containing diverse metal ions, some of which are summarized in Table 1. The sodium salt of D2EHPA (NaD2EHPA) has also been used to extract $\mathrm{Zn}$ (II) from sulfuric solutions. ${ }^{4,11)}$ To the best of our knowledge, little research has reported on the separation of $\mathrm{Ag}(\mathrm{I})$ and $\mathrm{Zn}$ (II) from the nitrate leach solutions of spent silver oxide batteries using D2EHPA.

In this study, extraction separation of $\mathrm{Ag}(\mathrm{I})$ and $\mathrm{Zn}(\mathrm{II})$ from the synthetic nitrate leach solution of spent silver oxide batteries was investigated by solvent extraction and stripping. For this purpose, D2EHPA was employed to study the extraction behavior of $\mathrm{Ag}(\mathrm{I})$ and $\mathrm{Zn}(\mathrm{II})$. The co-extracted $\operatorname{Ag}(\mathrm{I})$ and $\mathrm{Zn}(\mathrm{II})$ into the D2EHPA were separated by selective stripping with acidic thiourea and nitric acid solution. A process flowsheet for the separation and recovery of $\mathrm{Zn}(\mathrm{II})$ and $\operatorname{Ag}(\mathrm{I})$ from the nitrate leach solution of spent silver oxide batteries was proposed.

\section{Materials and Methods}

\subsection{Reagents}

$\mathrm{AgNO}_{3}$ (99.8\%, Daejung Chemicals and Metals Co., Ltd.) and $\mathrm{Zn}\left(\mathrm{NO}_{3}\right)_{2} \cdot 6 \mathrm{H}_{2} \mathrm{O}(98.0 \%$, Daejung Chemical and Metals Co., Ltd.) were dissolved in distilled water to prepare the feed

*Corresponding author, E-mail: spp1227@jnu.ac.kr; spp1227@hotmail.com solution. In all the experiments, the concentrations of $\mathrm{Ag}(\mathrm{I})$ and $\mathrm{Zn}$ (II) were maintained at 30 and $6 \mathrm{~g} / \mathrm{dm}^{3}$, respectively, to mimic the leach solution. $\left.{ }^{6}\right) \mathrm{HNO}_{3}(60 \%$, Daejung Chemicals and Metals Co., Ltd.) was used to adjust the acidity of the solution.

Di-(2-ethylhexyl) phosphoric acid (D2EHPA) (95\%, Alfa Aesar) was used without further purification. Pure kerosene (Daejung Chemicals and Metals Co., Ltd.,) was used as a diluent. Thiourea (98\%, Junsei Chemical Co., Ltd.) and $\mathrm{HNO}_{3}(60 \%$, Daejung Chemicals and Metals Co., Ltd.) were used in preparing the strippant solutions. Each strippant solution was prepared by dissolving the required amount of the reagent in the desired volume of distilled water.

\subsection{Procedure}

The general batch extraction and stripping experiment were carried out by mixing equal volumes $(20 \mathrm{~mL})$ of the aqueous and organic solutions for $30 \mathrm{~min}$ using a wrist shaker (Burrell, USA). All the experiments were performed at ambient temperature $\left(25 \pm 1^{\circ} \mathrm{C}\right)$. After equilibrium, the two phases were separated using separation funnels and the metal ion concentration in the aqueous phase was measured by ICP-OES (PerkinElmer Optima 8300). The metal ion concentration in the organic phase was calculated by mass balance. The $\mathrm{pH}$ value was measured before and after extraction with a $\mathrm{pH}$ meter (Thermo Orion star A211). The experimental chart for batch extraction and stripping experiments and the separation state of solution are shown in Figs. 1 and 2. The extraction percentage of metal ion is calculated as follows,

$$
\begin{aligned}
& \text { Extraction percentage }(\%)=\left(\mathrm{c}_{\mathrm{o}} / \mathrm{c}_{\mathrm{a}, 1}\right) \times 100 \% \\
& \quad=\left[\left(\mathrm{c}_{\mathrm{a}, 1}-\mathrm{c}_{\mathrm{a}, 2}\right) / \mathrm{c}_{\mathrm{a}, 1}\right] \times 100 \%
\end{aligned}
$$

where $c_{o}$ is metal ion concentration in the loaded organic phase, $\mathrm{c}_{\mathrm{a}, 1}$ and $\mathrm{c}_{\mathrm{a}, 2}$ is metal ion concentration in the aqueous phase before and after extraction, respectively.

The stripping percentage of metal ion is calculated by eq. (2),

$$
\text { Stripping percentage }(\%)=\left(\mathrm{c}_{\mathrm{a}, \mathrm{s}} / \mathrm{c}_{\mathrm{o}}\right) \times 100 \%
$$

where $c_{a, s}$ is metal ion concentration in the aqueous phase 
Table 1 Literature survey for the separation/extraction of $\mathrm{Zn}(\mathrm{II})$ from various solutions.

\begin{tabular}{lll}
\hline $\begin{array}{l}\text { Feed } \\
\text { composition }\end{array}$ & Media & Conditions \\
\hline & & $\begin{array}{l}\text { Zn was extracted in the } \mathrm{pH} \text { ranges } 2.5-3.0 \text { and 3.0-4.0 } \\
\text { with D2EHPA and PC } 88 \mathrm{~A} \text { in toluene, respectively. Zn }\end{array}$ \\
$\mathrm{Zn}, \mathrm{Cu}$ & $\begin{array}{l}\text { Perchlorate } \\
\text { solution }\end{array}$ & $\begin{array}{l}\text { was stripped with } 4.0 \mathrm{~mol} / \mathrm{dm}^{3} \mathrm{HCl} \text {. The probable } \\
\text { extracted species was } \mathrm{ZnR}_{2} \cdot 2 \mathrm{HR} \text { for both extractants. }\end{array}$
\end{tabular}

Ref.

Bioleaching $\mathrm{Cu}$ was extracted with LIX984N; Fe was removed by $\mathrm{Cu}, \mathrm{Zn}, \mathrm{Fe}$ of re-floated precipitation; $\mathrm{Zn}$ was recovered by extraction with tailings D2EHPA followed by stripping with $\mathrm{H}_{2} \mathrm{SO}_{4}$.

$99 \%$ of $\mathrm{Zn}$ was extracted by mixed extractant $(0.58$

$\mathrm{Zn}, \mathrm{Fe} \quad$ Hydrochloric mol$/ \mathrm{dm}^{3} \mathrm{TBP}: 0.12 \mathrm{~mol} / \mathrm{dm}^{3} \mathrm{D} 2 \mathrm{EHPA}$ ) at A/O ratio of solution $\quad 2 / 1$ and equilibrium $\mathrm{pH}$ of 3 . Stripping data was not available.

$\mathrm{Zn}, \mathrm{Pb}, \mathrm{Fe}$,
$\mathrm{Mn}, \mathrm{Ni}, \mathrm{Co}$, Sulfuric
$\mathrm{Ca}$

$\mathrm{Zn}, \mathrm{Cd}, \mathrm{Co}$, $\mathrm{Fe}, \mathrm{Pb}, \mathrm{Ca}$, $\mathrm{Mg}, \mathrm{Mn}, \mathrm{Ni}$ solution
Zn was extracted at pH 2.5 with $20 \%$ (w/w) D2EHPA in kerosene. Tributyl phosphate (TBP) as modifier, $\mathrm{Na}_{2} \mathrm{SO}_{4}$ as salting-out agent increased the extraction of $\mathrm{Zn}$.

$98 \%$ of $\mathrm{Zn}$ was extracted at $\mathrm{pH} 2.5$ with $20 \%$ (w/w) D2EHPA, A/O = 1/1, in three stages.

Stripping of $\mathrm{Zn}$ was obtained by $1.85 \mathrm{~mol} / \mathrm{dm}^{3} \mathrm{H}_{2} \mathrm{SO}_{4}$ at $\mathrm{A} / \mathrm{O}=1 / 4$, in three stages.

$\mathrm{Zn}, \mathrm{Cd}$ Phosphoric The extraction mechanisms of $\mathrm{Zn}$ and $\mathrm{Cd}$ in 5.5 solution $\quad \mathrm{mol} / \mathrm{dm}^{3}$ phosphoric acid solution were investigated.

\author{
)
}

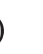

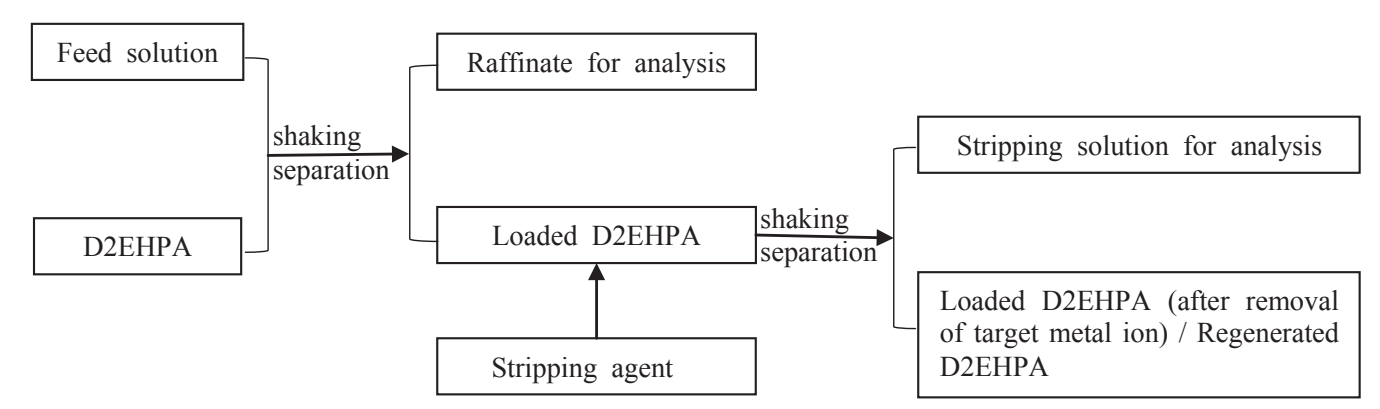

Fig. 1 The experimental flow chart for the batch extraction and stripping experiment.

after stripping, $\mathrm{c}_{\mathrm{o}}$ is metal ion concentration in the loaded organic phase.

\section{Results and Discussion}

\subsection{Effect of equilibrium $\mathrm{pH}$ on the extraction of metals}

The effect of the equilibrium $\mathrm{pH}$ on the extraction of $\mathrm{Ag}(\mathrm{I})$ and $\mathrm{Zn}$ (II) was investigated by varying the initial $\mathrm{pH}$ of the feed solution from 0.66 to 3.07 . The corresponding change in equilibrium $\mathrm{pH}$ was from 0.63 to 1.47 . The $\mathrm{Ag}(\mathrm{I})$ and $\mathrm{Zn}(\mathrm{II})$ concentrations in these experiments were fixed at 30 and $6.8 \mathrm{~g} / \mathrm{dm}^{3}$, respectively, while the concentration of D2EHPA diluted in kerosene was maintained at $0.5 \mathrm{~mol} / \mathrm{dm}^{3}$.

The results are represented as the extraction percentages of the metals as functions of the equilibrium $\mathrm{pH}$ in Fig. 3. The extraction of $\operatorname{Ag}(\mathrm{I})$ is $0 \sim 5 \%$ in all extraction experiments, and its extraction percentage is not evidently effected by varying the equilibrium $\mathrm{pH}$. The extraction percentage of 

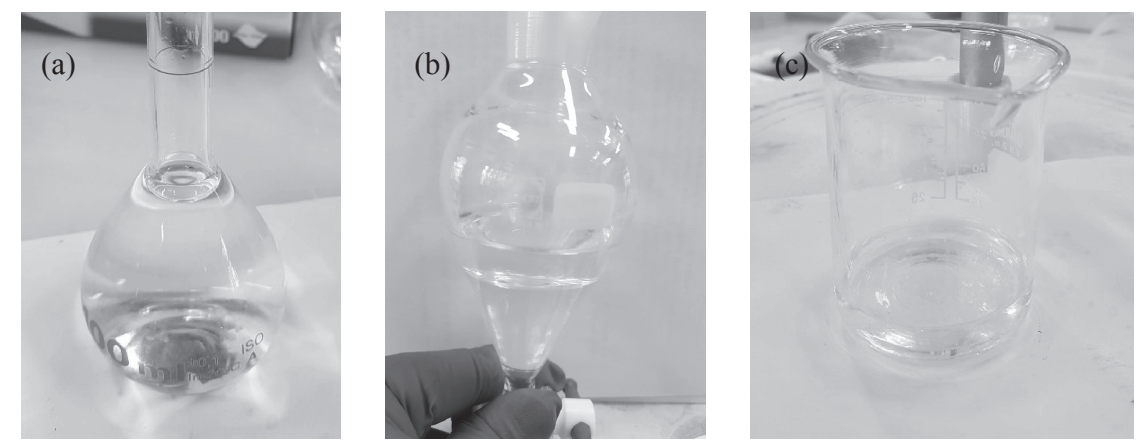

Fig. 2 Separation state of the solution. Feed solution: Ag-30g $/ \mathrm{dm}^{3}, \mathrm{Zn}-6 \mathrm{~g} / \mathrm{dm}^{3}, \mathrm{HNO}_{3}-0.1 \mathrm{~mol} / \mathrm{dm}^{3}$; D2EHPA-0.5 mol $/ \mathrm{dm}^{3}$ a) Feed solution b) Mixture of feed solution and D2EHPA after shaking for $30 \mathrm{~min}$ c) Raffinate after separation.

Table 2 The $\mathrm{pH}$ of solutions before and after extraction.

\begin{tabular}{llllll}
\hline Initial $\mathrm{pH}$ & 3.07 & 2.68 & 2.09 & 1.19 & 0.66 \\
\hline Equilibrium $\mathrm{pH}$ & 1.47 & 1.34 & 1.11 & 0.99 & 0.63 \\
\hline
\end{tabular}

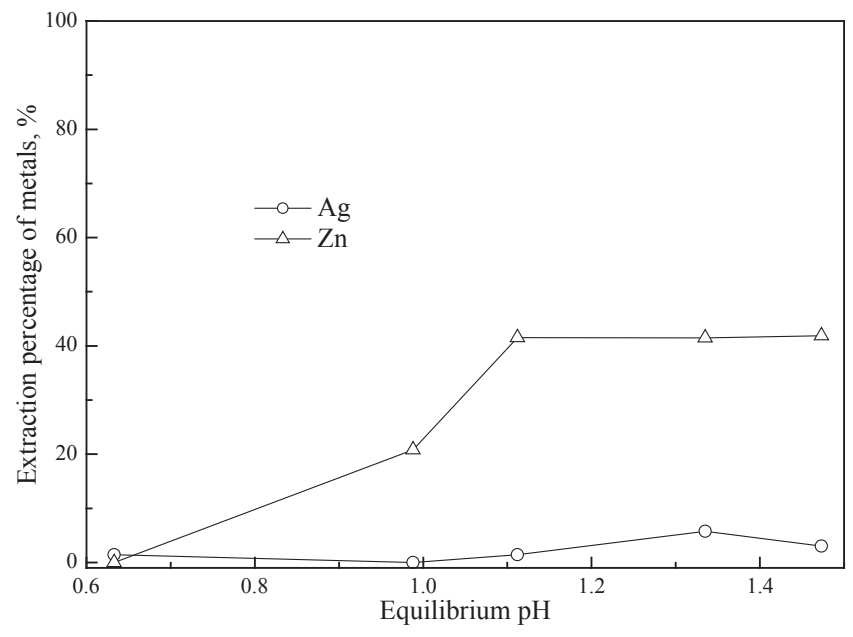

Fig. 3 Effect of equilibrium $\mathrm{pH}$ on the extraction of metals using 0.5 $\mathrm{mol} / \mathrm{dm}^{3}$ D2EHPA.

$\mathrm{Zn}(\mathrm{II})$ is increased with increasing equilibrium $\mathrm{pH}$ of the solution from 0.63 to 0.99 , and kept nearly the same with further increasing equilibrium $\mathrm{pH}$ of the solution to 1.47 . Therefore, it is possible to separate large part of $\mathrm{Ag}(\mathrm{I})$ from $\mathrm{Zn}$ (II) with D2EHPA when the equilibrium $\mathrm{pH}$ is $>1$ (initial $\mathrm{pH}$ of the feed solutions $>0.99)$. The $\mathrm{pH}$ of the solution before and after extraction is summarized in Table 2. Decreasing $\mathrm{pH}$ indicates that the extraction of $\mathrm{Zn}$ (II) with D2EHPA follows a classical cationic extraction mechanism. Since D2EHPA exists as a dimer, ${ }^{12}$ the extraction reaction can be represented as follows,

$$
\begin{aligned}
& \mathrm{Zn}^{2+}+(\mathrm{HR})_{2}=\mathrm{ZnR}_{2} \cdot 2 \mathrm{HR}+2 \mathrm{H}^{+} \\
& \mathrm{Ag}^{+}+(\mathrm{HR})_{2}=\mathrm{AgR} \cdot \mathrm{HR}+\mathrm{H}^{+}
\end{aligned}
$$

where $(\mathrm{HR})_{2}$ denotes the dimer of D2EHPA.

\subsection{Effect of D2EHPA concentration on extraction of metals}

In order to investigate the effect of D2EHPA concentration on the extraction of metals, the concentration of D2EHPA

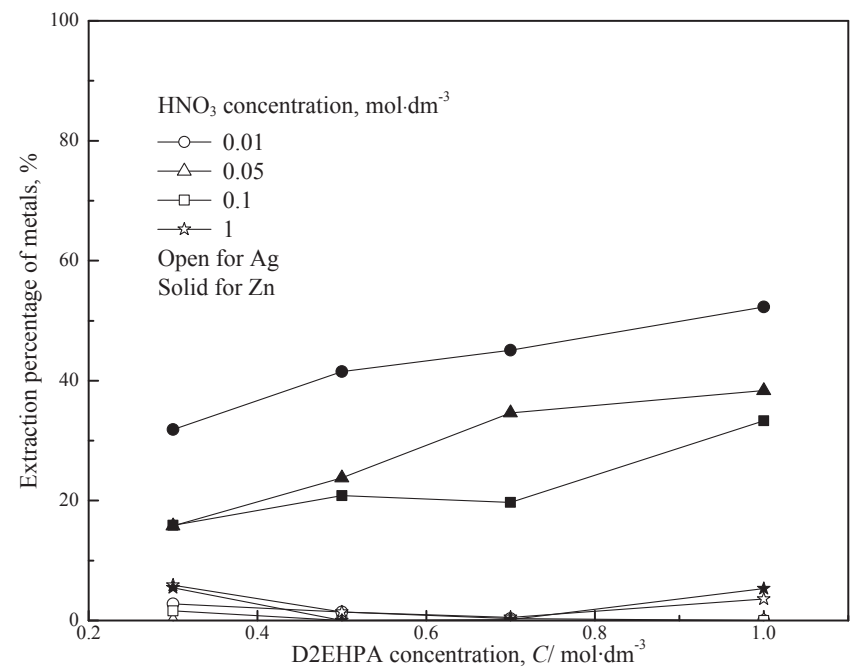

Fig. 4 Effect of D2EHPA concentration on the extraction of metals.

was varied from 0.3 to $1 \mathrm{~mol} / \mathrm{dm}^{3}$. The concentration of $\mathrm{HNO}_{3}$ in the feed solution was varied from 0.01 to 1 $\mathrm{mol} / \mathrm{dm}^{3}$, while the concentrations of $\mathrm{Ag}(\mathrm{I})$ and $\mathrm{Zn}$ (II) were fixed at 30 and $6.8 \mathrm{~g} / \mathrm{dm}^{3}$, respectively.

The results in Fig. 4 demonstrate the effect of the D2EHPA on the extraction percentages of $\mathrm{Ag}(\mathrm{I})$ and $\mathrm{Zn}$ (II) at various $\mathrm{HNO}_{3}$ concentrations. The extraction percentages of $\mathrm{Ag}(\mathrm{I})$ in all these extraction experiments are $0 \sim 5 \%$. For $\mathrm{Zn}(\mathrm{II})$, the extraction percentage of $\mathrm{Zn}$ (II) is increased with increasing D2EHPA concentration at a fixed acid concentration, but decreased with increasing $\mathrm{HNO}_{3}$ concentration at a fixed D2EHPA concentration. In the case of feed solution with $0.01 \mathrm{~mol} / \mathrm{dm}^{3} \mathrm{HNO}_{3}$ (initial $\mathrm{pH}=1.98$ ), the $\mathrm{pH}$ value of the solution after extraction varied from 1.45 to 1.32 with increasing D2EHPA concentration from 0.3 to $1 \mathrm{~mol} / \mathrm{dm}^{3}$.

The results obtained in Fig. 4 indicated that D2EHPA was selective for the extraction of $\mathrm{Zn}(\mathrm{II})$ over $\mathrm{Ag}(\mathrm{I})$ at low $\mathrm{HNO}_{3}$ concentrations. The separation of $\mathrm{Ag}(\mathrm{I})$ and $\mathrm{Zn}(\mathrm{II})$ with $1 \mathrm{~mol} / \mathrm{dm}^{3}$ D2EHPA from $0.01 \mathrm{~mol} / \mathrm{dm}^{3} \mathrm{HNO}_{3}$ was further investigated. 


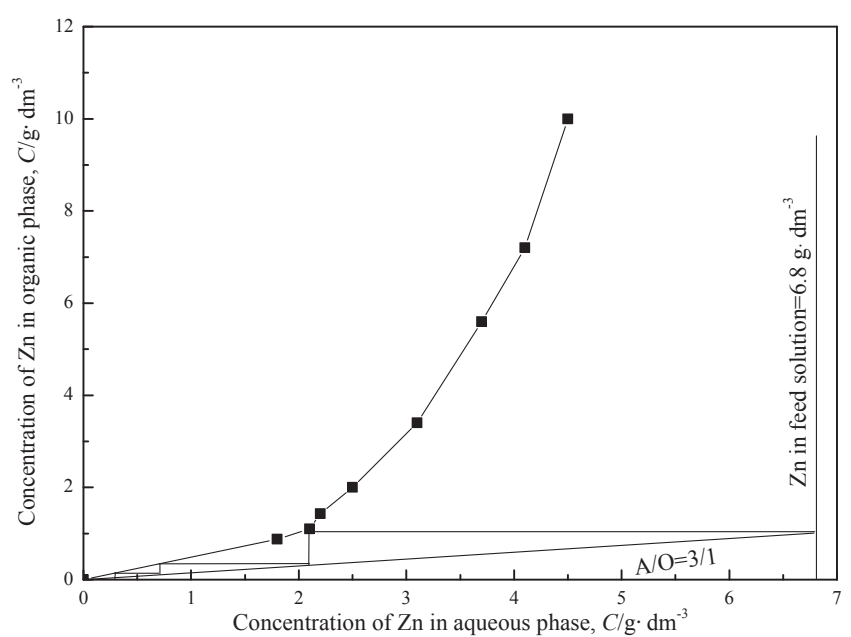

Fig. 5 McCabe-Thiele plot for extraction of $\mathrm{Zn}(\mathrm{II})$ with $1 \mathrm{~mol} / \mathrm{dm}^{3}$ D2EHPA.

\subsection{McCabe-Thiele plot for extraction of $\mathrm{Zn}$ (II) with D2EHPA}

A McCabe-Thiele plot was constructed by varying the volume ratio of the aqueous to organic phases (A/O ratio) from $5 / 1$ to $1 / 3$ to determine the theoretical number of stages required for the complete extraction of $\mathrm{Zn}$ (II) from the feed solution containing $30 \mathrm{~g} / \mathrm{dm}^{3} \mathrm{Ag}(\mathrm{I})$ and $6.8 \mathrm{~g} / \mathrm{dm}^{3} \mathrm{Zn}(\mathrm{II})$. The concentrations of D2EHPA in the organic phase and that of $\mathrm{HNO}_{3}$ in the feed solution were fixed at 1 and 0.01 $\mathrm{mol} / \mathrm{dm}^{3}$, respectively. The extraction of $\mathrm{Zn}(\mathrm{II})$ increased from 30.8 to $66.2 \%$ (the concentration of $\mathrm{Zn}$ (II) in the raffinate solution decreased from 4.5 to $2.2 \mathrm{~g} / \mathrm{dm}^{3}$ ) as the $\mathrm{A} / \mathrm{O}$ ratio was decreased from $5 / 1$ to $1 / 3$. The extraction percentage of $\operatorname{Ag}(\mathrm{I})$ was lower than $6.8 \%$ for all studied $\mathrm{A} / \mathrm{O}$ ratios (not shown in figure). The separation ratio of $\mathrm{Zn}$ (II) to $\mathrm{Ag}(\mathrm{I})$ decreased from 130.67 to 26.88 as the A/O ratio was decreased from $5 / 1$ to $1 / 3$. Figure 5 illustrates the McCabeThiele plot for $\mathrm{Zn}(\mathrm{II})$ extraction. The results indicate that three stages are required to obtain a quantitative extraction of $\mathrm{Zn}$ (II) using $1 \mathrm{~mol} / \mathrm{dm}^{3} \mathrm{D} 2 \mathrm{EHPA}$ at the A/O ratio of $1 / 3$.

Based on the results obtained from the McCabe-Thiele plot, a three-stage counter-current batch simulation test was performed at an $\mathrm{A} / \mathrm{O}$ ratio of $1 / 3$ using $1 \mathrm{~mol} / \mathrm{dm}^{3}$ D2EHPA. For each stage, the initial $\mathrm{pH}$ was maintained at $2( \pm 0.05)$. After the three-stage counter-current extraction, $99.99 \%$ of $\mathrm{Zn}(\mathrm{II})$ and $6.78 \% \mathrm{Ag}(\mathrm{I})$ were extracted from the aqueous solution, leaving most of $\mathrm{Ag}(\mathrm{I})$ in the raffinate. The $\mathrm{Ag}(\mathrm{I})$ and $\mathrm{Zn}(\mathrm{II})$ concentrations in the raffinate were 27.966 and $0.0068 \mathrm{~g} / \mathrm{dm}^{3}$, respectively, indicating that the purity of $\operatorname{Ag}(\mathrm{I})$ was $99.98 \%$. The $\operatorname{Ag}(\mathrm{I})$ and $\mathrm{Zn}(\mathrm{II})$ concentrations in the loaded D2EHPA were 0.678 and $2.264 \mathrm{~g} / \mathrm{dm}^{3}$, respectively.

\subsection{Selection of strippant for stripping of $\operatorname{Ag}(\mathrm{I})$ and Zn(II) from loaded D2EHPA}

In order to recover $\mathrm{Ag}(\mathrm{I})$ and $\mathrm{Zn}$ (II) from the loaded D2EHPA, stripping experiments were performed by using $\mathrm{HNO}_{3}$ and a mixture of $0.01 \mathrm{~mol} / \mathrm{dm}^{3} \mathrm{HNO}_{3}$ and thiourea as strippants. Based on the hard and soft acid and base theory (HSAB theory), thiourea is a soft ligand and effective in stripping of $\mathrm{Ag}^{+}$from the loaded organic phase. The

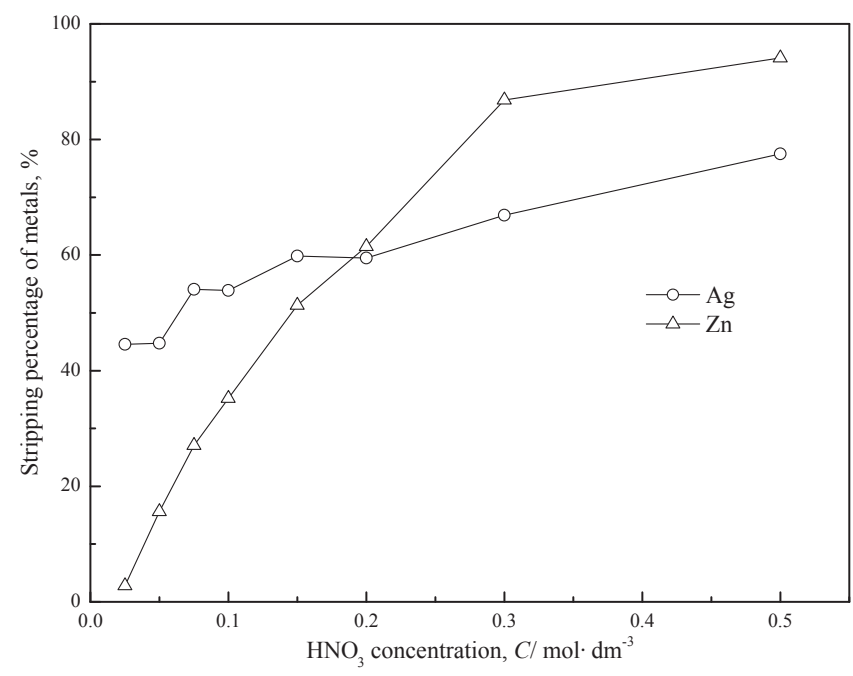

Fig. 6 Stripping of metals with various concentrations of $\mathrm{HNO}_{3}$ solutions.

loaded D2EHPA was obtained by mixing the feed solution containing $30 \mathrm{~g} / \mathrm{dm}^{3} \mathrm{Ag}(\mathrm{I}), 6.8 \mathrm{~g} / \mathrm{dm}^{3} \mathrm{Zn}$, and $0.01 \mathrm{~mol} / \mathrm{dm}^{3}$ $\mathrm{HNO}_{3}$ with $1 \mathrm{~mol} / \mathrm{dm}^{3} \mathrm{D} 2 \mathrm{EHPA}$ at an $\mathrm{A} / \mathrm{O}$ ratio of $1 / 1$. The concentrations of $\mathrm{Ag}(\mathrm{I})$ and $\mathrm{Zn}$ (II) in the loaded D2EHPA were 0.6 and $2.9 \mathrm{~g} / \mathrm{dm}^{3}$, respectively. Then the loaded D2EHPA was mixed with $\mathrm{HNO}_{3}$ and thiourea solutions of various concentrations, respectively.

Figure 6 shows the stripping percentages of $\operatorname{Ag}(\mathrm{I})$ and $\mathrm{Zn}$ (II) with various $\mathrm{HNO}_{3}$ concentrations. The stripping percentages of both $\mathrm{Ag}(\mathrm{I})$ and $\mathrm{Zn}(\mathrm{II})$ are increased with increasing $\mathrm{HNO}_{3}$ concentration. When the concentration of $\mathrm{HNO}_{3}$ is higher than $0.2 \mathrm{~mol} / \mathrm{dm}^{3}$, both $\mathrm{Ag}(\mathrm{I})$ and $\mathrm{Zn}(\mathrm{II})$ can be quantitatively stripped from the loaded D2EHPA. Thus, it is difficult to recover $\mathrm{Ag}(\mathrm{I})$ and $\mathrm{Zn}$ (II) separately by using $\mathrm{HNO}_{3}$ as the strippant. The stripping reaction can be represented as follows,

$$
\mathrm{ZnR}_{2} \cdot 2 \mathrm{HR}+2 \mathrm{H}^{+}=\mathrm{Zn}^{2+}+2(\mathrm{HR})_{2}
$$

where $(\mathrm{HR})_{2}$ denotes the dimer of D2EHPA.

For the stripping experiments using mixture of 0.01 $\mathrm{mol} / \mathrm{dm}^{3} \mathrm{HNO}_{3}$ and thiourea as the strippant, the results (Fig. 7) show that the stripping percentage of $\operatorname{Ag}(\mathrm{I})$ is increased with increasing thiourea concentrations, and $84.5 \%$ stripping of $\operatorname{Ag}(\mathrm{I})$ is obtained with $1 \mathrm{~mol} / \mathrm{dm}^{3}$ thiourea. In all studied thiourea concentration ranges, the concentration of $\mathrm{Zn}$ (II) in the obtained stripping solution is negligible. Therefore, the mixture of $0.01 \mathrm{~mol} / \mathrm{dm}^{3} \mathrm{HNO}_{3}$ and 1 $\mathrm{mol} / \mathrm{dm}^{3}$ thiourea was used in the following experiments to selectively strip $\operatorname{Ag}(\mathrm{I})$ from the loaded D2EHPA. The stripping reaction can be represented as follows, ${ }^{18)}$

$$
\mathrm{AgR} \cdot \mathrm{HR}+3 \mathrm{Th}+\mathrm{H}^{+}=\mathrm{Ag}(\mathrm{Th})_{3}{ }^{+}+(\mathrm{HR})_{2}
$$

where $(\mathrm{HR})_{2}$ and Th denotes the dimer of D2EHPA and thiourea, respectively.

\subsection{McCabe-Thiele plot for stripping of $\operatorname{Ag}(\mathrm{I})$ with acidic thiourea}

A McCabe-Thiele plot for the stripping of $\mathrm{Ag}(\mathrm{I})$ was constructed by varying the $\mathrm{A} / \mathrm{O}$ ratio from $1 / 3$ to $2 / 1$ to estimate the number of stages and phase ratios to complete the stripping of $\operatorname{Ag}(\mathrm{I})$ from the loaded D2EHPA with a 


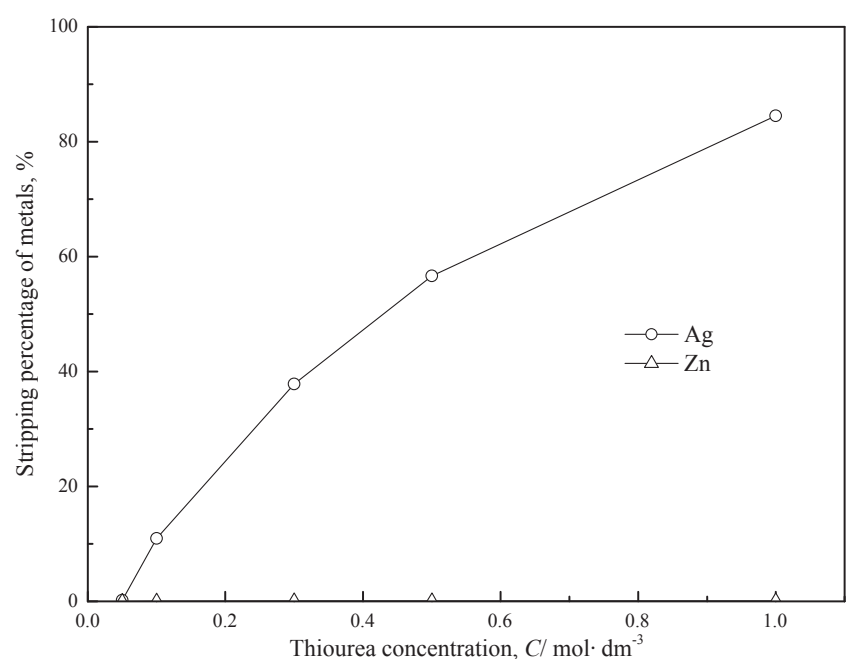

Fig. 7 Stripping of metals with various concentrations of thiourea solution.

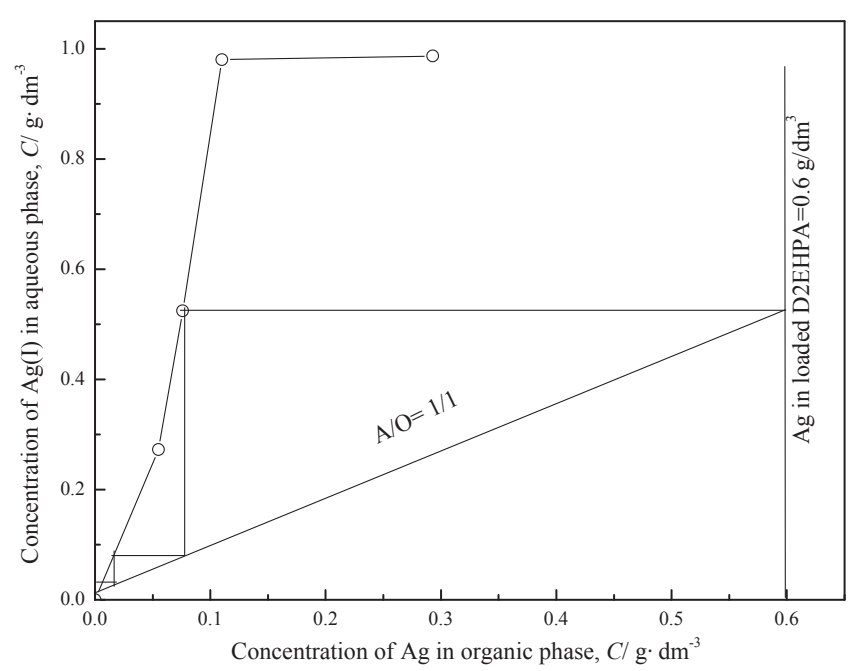

Fig. 8 McCabe-Thiele plot for stripping of $\mathrm{Ag}(\mathrm{I})$ with $1 \mathrm{~mol} / \mathrm{dm}^{3}$ thiourea.

mixture of $0.01 \mathrm{~mol} / \mathrm{dm}^{3} \mathrm{HNO}_{3}$ and $1 \mathrm{~mol} / \mathrm{dm}^{3}$ thiourea. The above described loaded D2EHPA containing $0.6 \mathrm{~g} / \mathrm{dm}^{3}$ $\mathrm{Ag}(\mathrm{I})$ and $2.9 \mathrm{~g} / \mathrm{dm}^{3} \mathrm{Zn}(\mathrm{II})$ was mixed with the mixture of $0.01 \mathrm{~mol} / \mathrm{dm}^{3} \mathrm{HNO}_{3}$ and $1 \mathrm{~mol} / \mathrm{dm}^{3}$ thiourea at varying $\mathrm{A} / \mathrm{O}$ ratios. The stripping percentage of $\mathrm{Ag}(\mathrm{I})$ was increased from $51.1 \%$ to $90.8 \%$ as the $\mathrm{A} / \mathrm{O}$ ratio increased from $1 / 3$ to $2 / 1$. The concentration of $\mathrm{Zn}$ (II) in the stripping solution was negligible. The results (Fig. 8) indicate that three countercurrent stripping stages are required for the complete stripping of $\mathrm{Ag}(\mathrm{I})$ from the loaded D2EHPA at the A/O ratio of $1 / 1$.

To verify the theoretical stripping stages obtained from the McCabe-Thiele plot, a batch simulation test was performed. The loaded D2EHPA was obtained by batch simulation experiments of three-stage counter-current extraction, and the concentrations of $\mathrm{Ag}(\mathrm{I})$ and $\mathrm{Zn}$ (II) were 0.68 and $2.26 \mathrm{~g} / \mathrm{dm}^{3}$, respectively. The mixture of $0.01 \mathrm{~mol} / \mathrm{dm}^{3} \mathrm{HNO}_{3}$ and 1 $\mathrm{mol} / \mathrm{dm}^{3}$ thiourea was used as the strippant and the $\mathrm{A} / \mathrm{O}$ ratio was maintained at $1 / 1$. The results suggested that $\operatorname{Ag}(\mathrm{I})$ was completely stripped after the three-stage counter-current stripping, while the concentration of $\mathrm{Zn}$ (II) in the stripping solution was negligible. The concentration of $\mathrm{Zn}$ (II) was $2.26 \mathrm{~g} / \mathrm{dm}^{3}$ in the loaded D2EHPA after removal of $\mathrm{Ag}(\mathrm{I})$.

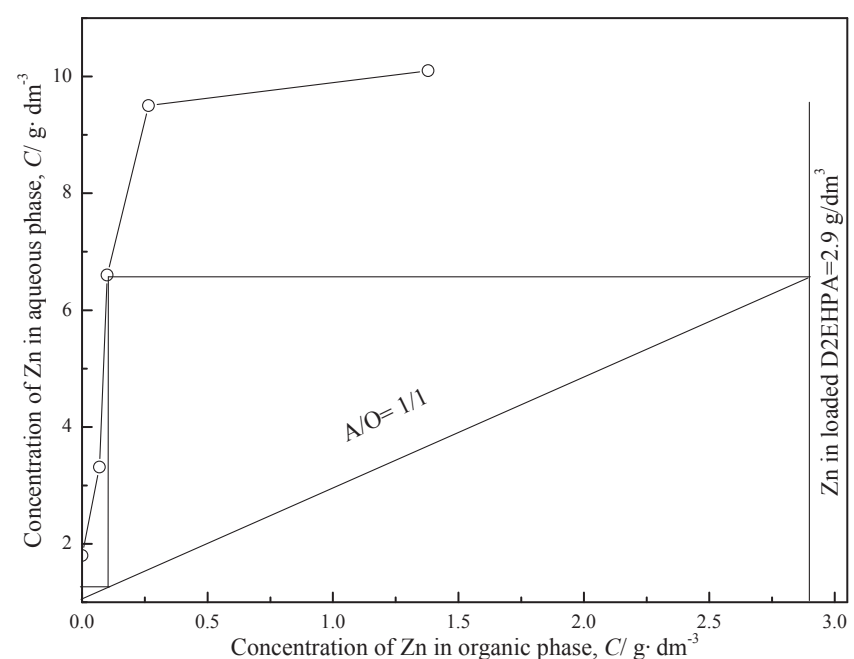

Fig. 9 McCabe-Thiele plot for stripping of $\mathrm{Zn}(\mathrm{II})$ with $0.5 \mathrm{~mol} / \mathrm{dm}^{3} \mathrm{HNO}_{3}$ after removal of $\mathrm{Ag}(\mathrm{I})$.

\subsection{McCabe-Thiele plot for stripping of $\mathrm{Zn}$ (II) with $\mathrm{HNO}_{3}$ after removal of $\mathrm{Ag}(\mathrm{I})$}

Based on the results in Fig. 6, $\mathrm{HNO}_{3}$ can strip $\mathrm{Zn}$ (II) from the loaded D2EHPA. Therefore, $0.5 \mathrm{~mol} / \mathrm{dm}^{3} \mathrm{HNO}_{3}$ was selected as the strippant to recover $\mathrm{Zn}$ (II) from loaded D2EHPA after the removal of $\mathrm{Ag}(\mathrm{I})$.

A McCabe-Thiele plot for the stripping of $\mathrm{Zn}$ (II) was constructed by varying the $\mathrm{A} / \mathrm{O}$ ratio from $1 / 3$ to $5 / 1$ to estimate the number of stages and phase ratios to complete the stripping of $\mathrm{Zn}$ (II) from the loaded D2EHPA with $0.5 \mathrm{~mol} / \mathrm{dm}^{3} \mathrm{HNO}_{3}$. The loaded D2EHPA was prepared by mixing the feed solution containing $\mathrm{Ag}(\mathrm{I})$ and $\mathrm{Zn}$ (II) with $1 \mathrm{~mol} / \mathrm{dm}^{3}$ of D2EHPA at $0.01 \mathrm{~mol} / \mathrm{dm}^{3}$ of $\mathrm{HNO}_{3}$. The A/O ratio was $1 / 1 . \mathrm{Ag}(\mathrm{I})$ was removed by three stages of countercurrent stripping with $1 \mathrm{~mol} / \mathrm{dm}^{3}$ thiourea. The concentration of $\mathrm{Zn}(\mathrm{II})$ in the loaded D2EHPA was $2.9 \mathrm{~g} / \mathrm{dm}^{3}$. The results (Fig. 9) indicate that two counter-current stripping stages are required for the complete stripping of $\mathrm{Zn}$ (II) from the loaded D2EHPA at an A/O ratio of 1/1. D2EHPA can be regenerated after the complete stripping of $\mathrm{Zn}(\mathrm{II})$ with $\mathrm{HNO}_{3}$.

To verify the theoretical stripping stages obtained from the McCabe-Thiele plot, a two-stage counter-current batch simulation of the stripping experiments was performed. The loaded D2EHPA was obtained by batch simulation experiments of the three-stage counter-current extraction. After removing the $\mathrm{Ag}(\mathrm{I})$ with the mixture of $0.01 \mathrm{~mol} / \mathrm{dm}^{3} \mathrm{HNO}_{3}$ and $1 \mathrm{~mol} / \mathrm{dm}^{3}$ thiourea, the concentration of $\mathrm{Zn}$ (II) in the loaded D2EHPA was $2.26 \mathrm{~g} / \mathrm{dm}^{3} .0 .5 \mathrm{~mol} / \mathrm{dm}^{3} \mathrm{HNO}_{3}$ was used as a strippant and the phase ratio was maintained at $1 / 1$. According to the batch simulation stripping experiments, $\mathrm{Zn}$ (II) was almost completely stripped from the loaded D2EHPA. The $\mathrm{Zn}$ (II) concentration in the obtained stripping solution was $2.26 \mathrm{~g} / \mathrm{dm}^{3}$, while no $\operatorname{Ag}(\mathrm{I})$ was detected. This result indicated that the purity of $\mathrm{Zn}$ (II) was higher than 99.99\% (determination limit: $0.01 \mathrm{mg} / \mathrm{dm}^{3}$ ).

In the literature, ${ }^{19,20)} \mathrm{Ag}(\mathrm{I})$ and $\mathrm{Zn}$ (II) from nitrate leaching solution of silver oxide batteries were precipitated using $\mathrm{KCl} / \mathrm{NaCl}$, which is a commonly used method. Its disadvantage of needing expensive equipment and precipitant (including flocculating agent) is avoid in the present 


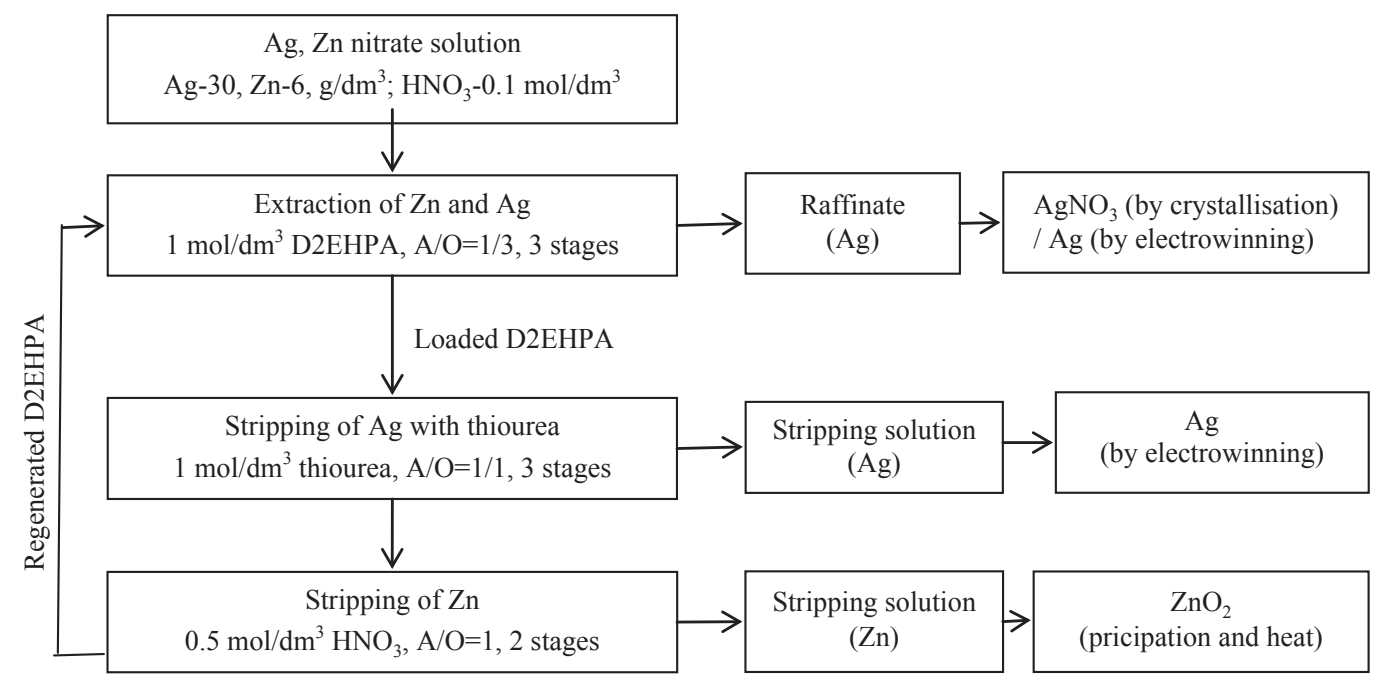

Fig. 10 Process flow sheet for the separation of $\mathrm{Ag}(\mathrm{I})$ and $\mathrm{Zn}(\mathrm{II})$ from nitrate leaching solution.

proposed process. ${ }^{21)}$ In addition, the present proceeding avoids using toxic chemicals and restricted disposal problems compared with that from cyanide medium. ${ }^{22}$ Thus, the present studied process is more environmentally friendly and has the potential to be applied in practice.

\section{Conclusions}

A liquid-liquid extraction process was developed for the separation of $\mathrm{Ag}(\mathrm{I})$ and $\mathrm{Zn}(\mathrm{II})$ from the nitrate leach solution of silver oxide batteries. The process flow sheet for the separation of $\mathrm{Ag}(\mathrm{I})$ and $\mathrm{Zn}(\mathrm{II})$ from the nitrate leach solution of silver oxide batteries is summarized in Fig. 10. The complete extraction of $\mathrm{Zn}$ (II) from the nitrate leach solution was achieved using $1 \mathrm{~mol} / \mathrm{dm}^{3}$ D2EHPA in three stages at an $\mathrm{A} / \mathrm{O}$ ratio of $1 / 3$, leaving most of the $\mathrm{Ag}(\mathrm{I})$ in the raffinate. The co-loaded $\operatorname{Ag}(\mathrm{I})$ was removed by stripping with a mixture of $0.01 \mathrm{~mol} / \mathrm{dm}^{3} \mathrm{HNO}_{3}$ and $1 \mathrm{~mol} / \mathrm{dm}^{3}$ thiourea in three stages at a $1 / 1 \mathrm{~A} / \mathrm{O}$ ratio. After the removal of $\mathrm{Ag}(\mathrm{I})$, $\mathrm{Zn}$ (II) loaded in D2EHPA was recovered by stripping with $0.5 \mathrm{~mol} / \mathrm{dm}^{3} \mathrm{HNO}_{3}$ in two stages at an $\mathrm{A} / \mathrm{O}$ ratio of $1 / 1$. Finally, this process was verified by batch simulation experiments of counter-current extraction and stripping to obtain $\operatorname{Ag}(\mathrm{I})$ and $\mathrm{Zn}(\mathrm{II})$ solutions with high purities.

\section{Acknowledgments}

This research was supported by the Basic Science Research Program (No: 2017R1D1A3B03030407) through the National Research Foundation of Korea (NRF) funded by the Ministry of Education. The authors are grateful for the financial support. The authors also express sincere thanks to the Korea Basic Science Institute (KBSI), Gwangju branch for providing the ICP-OES data.

\section{REFERENCES}

1) U. Jadhav and H. Hocheng: J. Clean. Prod. 44 (2013) 39-44.

2) P. Dias, P. Javimczik, M. Benevit, H. Veit and A.M. Bernardes: Waste Manag. 57 (2016) 220-225.

3) A. Kuczyńska-Łażewska, E. Klugmann-Radziemska, Z. Sobczak and T. Klimczuk: Sol. Energy Mater. Sol. Cells 176 (2018) 190-195.

4) H.Z. Long, L.Y. Chai, W.Q. Qin and S.H. Tang: J. Cent. South Univ. Technol. 17 (2010) 760-764.

5) S. Aktas: Hydrometallurgy 104 (2010) 106-111.

6) M.J. Smith and F.M. Gray: J. Chem. Educ. 87 (2010) 162-167.

7) Y. de Gaetano, I. Clarot and J.B. Regnouf-de-Vains: New J. Chem. 36 (2012) 1339-1346.

8) Z. Gamiño-Arroyo, A. Tapia-Cisneros, O. Zamacona-Saucedo, I. CanoRodríguez, A.F. Aguilera-Alvarado, L.E. Sánchez-Cadena and F.I. Gómez-Castro: J. Mater. Sci. Chem. Eng. 3 (2015) 148-153.

9) E.A. Mowafy and H.F. Aly: J. Hazard. Mater. 149 (2007) 465-470.

10) P.P. Sun, B.J. Min, S.T. Kim and S.Y. Cho: Mater. Trans. 58 (2017) 287-290.

11) K.C. Nathsarma and N. Devi: Hydrometallurgy 84 (2006) 149-154.

12) R.K. Singh and P.M. Dhadke: J. Serb. Chem. Soc. 67 (2002) 41-51.

13) W. Kitobo, S. Gaydardzhiev, J. Frenay, D. Bastin and I. Ndala: Sep. Sci. Technol. 45 (2010) 535-540.

14) A. Azizitorghabeh, F. Rashchi, A. Babakhani and M. Noori: Sep. Sci. Technol. 52 (2017) 476-486.

15) E. Vahidi, F. Rashchi and D. Moradkhani: Miner. Eng. 22 (2009) 204206.

16) D.D. Pereira, S.D.F. Rocha and M.B. Mansur: Sep. Purif. Technol. 53 (2007) 89-96.

17) A. Mellah and D. Benachour: Chem. Eng. Process. 45 (2006) 684-690.

18) A. Gherrou, H. Kerdjoudj, R. Molinari and E. Drioli: Sep. Purif. Technol. 22-23 (2001) 571-581.

19) S. Aktas and M.H. Morcali: Miner. Metall. Proc. 28 (2011) 198-203.

20) N. Sathaiyan, V. Nandakumar and P. Ramachandran: J. Power Sources 161 (2006) 1463-1468.

21) P. González, F. Javier Recio, D. Ribera, O. González, P. DaSilva, P. Herrasti and M. Avila-Rodriguez: Silver Recovery from Acidic Solutions by Formation of Nanoparticles and Submicroparticles of Ag on Microfiltration Membranes, (Mass Transfer - Advanced Aspects, InTech, 2011) pp. 439-460, DOI: 10.5772/21532.

22) F. Xie, D. Lu, H. Yang and D. Dreisinger: Miner. Process. Extr. Metall. Rev. 35 (2014) 229-238. 